AüifDXV(2005), say 1, s. 1-19

\title{
Klasik Bir Kelâm Problemi Olarak Rızık Kavramının Tanımları ve Bu Tanımların İçerdiği Problemler
}

\author{
MUHIT MERT \\ Doç. Dr. GAZI Ü. ÇORUM ILAHIYAT FAKÜLTESI \\ e-mail: mulitmert@hotmail.com
}

\begin{abstract}
The Definition of the Conception Rwq and Problems it Contains as a Classical Problem of Kalam. In this article, we aimed to deal with the definitions of conception nzq as a classical Muslim theologians problem of kalam and the problems the definitions contain. Muslim theologians defines nzq in different ways. The forms and the words they used in these definitions give clues of their main ideas on the issue. Morever, different definitions which belong to the theologians who are related to the same school point, different viwes within those schools. For these reason, analysing definitions is important from the view of scientific approach. In this context, the extent of nizq, whether the things obtained by unjust ways and haram (unlawful) from a religious point of view can be considered as nzq or not will be discussed.
\end{abstract}

key words

Rızq, Definition, Profit, Possesion, Forbidden by religion, Unlawful.

\section{Giriş}

Rızık kavramı klasik kelâmda kader ve/veya insan fiilleri konuları çerçevesinde ele alınmış; kavrama dair bir tanımlamadan sonra kaderle/insan fiilleriyle ilişkisi kurularak incelenmiştir. Ancak biz burada rızık ile ilgili tartışmaların bütün yönleriyle değil, sadece rızkın tanımıyla, bu tanımda kullanılan kavramların delaletleriyle ve tanımlama biçimlerinin içerdiği problemlerle ilgileneceğiz. Bunu yaparken de öncelikle rızkın sözlük ve kelâm disiplini içindeki terim anlamlarını belirleyecek, sonra da tanımların içerdiği problemlere geçeceğiz. 


\section{Rızkın Sözlük veTerim Anlamları}

Rızık (er-Rızk, çoğulư el-Erzâk) kelimesi, Arapça (Re-ze-ka) fiilinden türetilmiş bir isimdir. Ruzı́k sözlükte, kendisinden faydalanılan şey olarak tarif edilir. ${ }^{1}$ Arap dil bilimcileri rızık kelimesinin atâ (ihsan), pay, şükür, yağmur ve yiyecek manasındả kullanıldığını da tespit etmektedirler. ${ }^{2}$ Rızık kelimesinin buradaki her bî́r manada ayrı ayrı kullanıldığını göstermek için Kur'an'dan deliller gösterilir. Bunları şöyle sıralayabiliriz.

Ruzık kelimesi Kur'an'da; ister dünyevî olsun isterse uhrevî olsun maddî manevî ihsanlar manạsında kullanılmıștır. Meselâ; "Onlara rızık olarak verdiğimiz şeylerden infa'k ederler."3 ayetinde rızık ile, Allah'ın insana dünyada bahşettiği mal, amel, |güç ve ilim gibi maddî-manevî şeyler kastedilmekte; ${ }^{4}$ "Allah yolunda öldürülenleri ölü sanmayın, bilâkis onlar Rab'leri katında diridirler. Allah'ın bol ńlimetinden onlara verdiği şeylerle sevinç içinde rızıklanurlar"s ayetinde ise|sadece uhrevî ihsanlar anlatılmaktadır.

Râğıp el-Isfahânî (ö:502/1106) ile Fahreddin er-Razî (ö:606/1210) Vâkıa (56) sûresinin 82 ! ayetindeki rızık kelimesini pay/nasip manasına tefsir ederek "Siz nasibinizí yalanlamak için mi kullanıyorsunuz?" şeklinde anlarlar. ${ }^{\circ}$ Arapların Ezd kabilesi ise bu ayetteki rızık kelimesini şükür manasına yormuşlardır.' Buná göre ayetin anlamı "Siz şükrünüzü yalanlayarak mı yapıyorsunuz?" olmaktadır. Bu şekildeki anlamlandırma için kendilerinin kullandığı; "Faaltü zalike limâ razaktenî/Bana teşekküründen dolayı bunu yaptım" sözünü delil olarak ileri sürerler. ${ }^{8}$ İbn Manzûr (ö:711/1311) ise, ayetteki rızık kelimeșinin şükür manasına mecaz olarak kullanıldığını söylemektedir.9 Buna göre ayetin manası "Rızkınızın şükrünü yalanlayarak mı yapıyorsunuz?" olur.

Rızık yağmur anlamında da kullanılır. Rızkın yağmur manasına kullanılması ikisi arasındaki sebep-sonuç alâkasından dolayıdır. Yağmur rızka konu olan nesnelerin artışı́na sebep olduğu için ona mecaz olarak rızık da denir.

Murtaza ez-Zebîdî, Tâcu'l-Arûs, Beyrut 1994, XIII, 162; Muhammed b. Yakub el-Fîruzâbâdî, Kâmusu'l-muhit, Beyrut' 1987, s. 1144.

2 Butrus el-Bustânî, Muhitu'l-Muhît, Beyrut 1979, s. 333; Hasan Sid el-Kermî, el-Hâdî, Beyrut 1991, II, 160.

3 el-Bakara 2/3.

4 M. Handi Yazır, Hak Deni Kur'an Dili, İstanbul ty., I, 192.

$s$ Âl-i Imran 3/169.

- Fahreddin Râzî, Mefâtihü'l-gayb, Beyrut 1990, Il, 30; Râğıb el-Isfahânî, el-Müfredat, Beyrut ty., s. 194.

Fîruzâbâdî, a.g.e., s. 1144.

8 İbn Zekeriyya, Mu'cemú mekâyisi'l-luğa, Kahire h.1366, II, 388 .

? Ibn Manzûr, Lisanüll-arab. Beyrut ty., X, 115. 
Meselâ, "Rızkınız semadadır."10 ayetindeki rızık ile yağmurun kastedildiği söylenmiştir." Nitekim Câsiye sûresinin, "Allah'ın gökyüzünden rızık indirip ölmüs olan yeryüzünü onunla diriltmesinde akledenler için dersler var$d ı r^{\prime \prime 2}$ ayetinde de yağmur hakkında rızık tabiri kullanılmıştır. ${ }^{13}$ Bu kullanım, aralarındaki sebebiyet ilişkisi nedeniyledir. Araplar; "et-Temru fi ka'ri'l-bi'r/Hurma kuyunun dibindedir" derler. Halbuki gerçekte böyle değildir. Ancak hurma kuyunun dibindeki su ile sulanarak elde edildiği için böyle söylenmiştir. Yağmur da rızka sebep olduğu için ona rızık adı verilmiştir. ${ }^{14}$

Rızık kelimesi Kur'an'da sadece yenilen şeyler için de kullanılmaktadır. Meselâ, mağarada uzun süre uyumuş olan Ashâb-ı kehf uyandıktan sonra içlerinden birinin diğerlerine söylediği sözü nakleden "İçinizden birini şu gümüş paralarla şehre gönderin de baksın, yiyeceklerden en temizi hangisi ise size rızık (yiyecek) getirsin" 15 ayeti ile "Biz o su ile kullara rizlk olmak üzere bahçeler, biçilecek taneli ekinler, küme küme tomurcukları olan boylu hurma ağaçları yetiştirdik"16 ayetinde geçen rızık kelimeleri, sadece yenilen şeyler manasında kullanılmıştır.

Netice olarak, rızık kelimesinin kullanıldığı manaların tümünde kendisinden faydalanılan şey anlamının hakim olduğu görülmektedir.

Dinî bir terim olarak nızık kavramının, lügat manasından alınarak kelâm disiplini içerisinde ifade ettiği anlamı tam olarak belirlemek için kelâmcıların bu terimden ne anladıklarını tespit etmek gerekmektedir. Biz burada önemli düşünce farklılıklarına delalet eden bazı tanımları zikredeceğiz. Rızık kavramı kelâmcılar tarafından dört şekilde tanımlanmıştır:

1-İster helâl olsun isterse haram, beslendiğimiz gıdalar. Abdulkâhir elBağdâdî(ö.429/1038), Ebu Bekr Ahmed el-Beyhakî (ö.458/1066), Nureddin es-Sâbunî (ö.580/114), Adudüddin el-îcî (ö. 756/1355), Sadeddin etTaftazânî (ö.793/1390) ve Seyyid Şerif el-Cürcânî (ö. 816/1413) bu tanımı benimsemişlerdir.

2-Faydalandığımız şeyler. İmamü'l-Harameyn el-Cüveynî (ö. 478/1085), et-Taftazâni, İbn Haldun (ö.808/1405), Kemaleddin el-Beyâzî (ö.1097/ 1686), İbrahim el-Bâcûrî (ö.1277/1860), ve Elmalılı Hamdi Yazır (ö.1942) rızkı bu şekilde tanımlamışlardır.

\footnotetext{
ez-Zâriyât $51 / 22$.

Ebu'l-Fidâ İsmail İbn Kesir, Tefsiru'l-Kur'ani'l-azim, Beyrut 1969, VI, 235.

el-Câsiye 45/5.

Zebîdî, a.g.e., XIII, 162, el-Bustânî, a.g.e., s. 333; el-Kermî, a.g.e., II, 160.

Ibn Manzûr, a.g.e., X, 115.

el-Kehf 18/19.

Kâf 50/9-11.
} 
3-Faydalandığımız şeylerle birlikte sahip olduğumuz şeyler. Gazalî (ö.505/1111), Ebu'l-Muin en-Nesefî (ö. 508/1115), Fahreddin er-Razi (ö. 606/1210), ibn Teymiye (ö.728/1327), Muhammed Hüseyin et-Tabatabâî rızkn bu şekilde tanımlanması gerektiğini savunmuşlardır.

4-Meşrû (helâl) olàrak faydalandığı̆ıı şeyler. Ebu'l-Hüzeyl el-Allaf (ö. 135-226), Kâdî Abdülcebbâr (ö. 415/1025), Ebu Ali el-Fazl ỉbn el-Hasen et-Tabersî (ö.548/115'3), rızkı bu şekilde tanımlamışlardır. ${ }^{17}$

Burada naklettiğimiz tanımlardan anlaşıldığı kadarıla kelâmcılar rızık kavramının anlam alahını belirlerken onun hem sözlük anlamını göz önünde bulundurmuşlar, hem de dildeki kullanım örfünü esas almışlardır.

Rızkın Tanımıyla ilgilj Kelâmî Tartışmalar

Yukarıda zikrettiğimiż tanımlar üzerinde düşündüğümüzde temelde iki şeyin problem edinildiği gözlenmektedir. Bunlardan birincisi bir şeyin rızk olabilmesi için ondan lyararlanma şartı ve yararlanmanın nasıl olacağı, ikincisi rızkta meşruiyet problemi, yani haram bir şeyin rızık olup olmayacağı sorunudur.

a) Yararlanma Şartı ve Yararlanmanin Şekli

Rızık tanımlarına dikkat edildiğinde rızkın kök anlamı olan yararlanmanın esas alındığı görülür! Ancak hangi çeşit yararlanmayla rızıklanmanın gerçekleşeceği hususunda ihtilaf edilmiştir. Burada iki temel soru ortaya koyabiliriz:

1-Yeme-içmenin dışndaki faydalanmalar rızık kapsamına girer mi?

2-Faydalanılmayan fakat elimizde bulunan şeyler rızık olur mu?

Eş'arîlerden Abdu'lkâhir el-Bağdâdî, "Kim helâl veya haram bir şey yer içerse o, onun rızkıdır"'"18 demiştir. Beyhakî rızk, "Haram olsun, helâl olsun canliların gıdalandı̆̆ her şey onların rızkıdır"'19 şeklinde tanımlamışıı. Mâturîdî kelâm bilginlerinden Nureddin es-Sâbûnî rızks; "İster helâl olsun isterse haram, insanın |yediği şey onun rrzkıdır'20 diye tarif etmiştir. Eş'ari ekolü kelâmcılandan Adudüddin el-Îcî, "İster helâl olsun isterse haram, Al-

17 Bu tamımlann kaynaklanı çahısmanın ilerleyen kısınlarında yer verileceğinden, burada ayrıca atıfta bulunmaya gexiek duymadık.

w Abdulkâhir el-Bağdâdi, Usulüddin, İstanbul 1928, s. 144. Nispeti belli olmamakla birlikte bazı kaynaklarda Bağdâdíniı̀kine benzer bir tarif daha zikredilmektedir. Buna göre de rzzk "Canlılarn beslendiği gıdalar ve içecekler"dir. Seyyid Şerif el-Cürcânî, Şerhu'l-Mevâkıf, Kahire 1907, VIII, 172; Kemaleddin el-Beyâzî, İşấâtu'l-merâm min l̉âarâti'l-ìmam, Kahire 1949, s. 235; M. Ali b. Ali Tehânevî, Keşşsafu istulâhâtr'l-fünün, İstanbul 1984, I, 581.

19 Ebu Bekr Ahmed el-Beýhakî, el-itikad, Beynut 1985, s. 113.

o Nureddin es-Sâbûnî, el-Bidaye fî usûli'd-din (Matüridiyye Akaidi), çev. Bekir Topaloğlu, Ankara 1992 , s. 75 . 
lah'ın kişiye yemesi için verdiği şeydir"21 , Sa'deddin et-Taftazanî ile Seyyid Şerif el-Cürcânî de rızk, "Allah Teâlâ'nın canlıya, yemesi için verdiği şeydir ki, helâli de haramı da kapsar"22 diye tarif etmişlerdir.

$\mathrm{Bu}$ tanımlarda öne çıkan hususları şöyle sıralayabiliriz:

1-Bağdâdînin tanımında yeme ile birlikte içme de rızkın kapsamına ahnırken, diğerlerinde sadece yeme tabiri kullanılmıştır. Bu ya içmeyi yeme kapsamına aldıklarından, ya da onu tanımın dışında tutmak istediklerinden kaynaklanabilir. Bu ikincisi de muhtemel olmakla -ki Şerhu'l-Mevâkıfa haşiye yazan Hasan Çelebi böyle düşünmektedir ${ }^{23}$ - birlikte içmeyi yeme kapsamında düşündükleri daha muhtemeldir. Örneğin küçük çocuklar da sütle beslenmekteler ve bu da ruzıklanma anlamına gelir. Bu yüzden biz de yemeiçmeyi birlikte düşünüyoruz.

2-Bu tanımlarda rızık sadece yenilen-içilen şeylerden ibaret sayılmakta, bu suretle giyecekler ve kendisinden değişik yollarla yararlanılan diğer şeyler tanımın dışında bırakılmaktadır. Bu, dilde rızkın ağırlıklı olarak yenileniçilen şeyler için kullanılmasından kaynaklanmaktadır.

3-es-Sâbûnî ile el-Î́cî'nin tanımlarında sadece insan, rızıklandırma kapsamı içine alınırken, el-Beyhakî, et-Taftazânî ve el-Cürcânî’ninkinde diğer canlılar da bu kapsama dahil edilmiştir. Bu, onların diğer canlıların rızıklanmadığı düşüncesinde olduklarından değil, Mu'tezile tarafından insanın rızkı tartışma konusu yapıldığından ve rızkun kelâm ilminin temel konularından insan fiilleri konusu içinde ele alındığından kaynaklanmaktadır. Ancak doğru bir tanımlama yapılacaksa umumiyet ifade eden bir kelimenin kullanılması daha uygundur. Zira diğer canlılar da rızıklanmaktadırlar.

4-Bu tanımlarda helâl ve haram kavramlarıyla meşruiyet konusuna da atıf yapılmıştır. Bu atıf şüphesiz ki haramı rızık saymayan Mu'tezili düşünceyi reddetmek için konulmaktadır. Mu'tezile tarafından rızk tanımlarına haram kaydının konulması, rızkın diğer canlıları kapsayacak şekildeki tanımıyla çelişmektedir. Zira helâllik-haramlık mükellef insanla ilgili hükümlerdir. Ĕger rızık bütün canlılar içinse bu kaydın konulmaması gerekir. Dolayısıyla Ehl-i sünnetin haram-helâl kaydını koyması umumiyet ifade etmesi içindir. Ancak bu ifadeler tanımda yine de fazlalık kavramlar olarak durmaktadır.

2ı Adudüiddin el-Îcî, el-Mevâkıf, Beyrut ty., s. 320.

22 Sa'deddin Taftazânî, Şerhu'l- Akâid, İstanbul 1976, s. 127; Seyyid Şerif el-Cürcânî, et-Ta'rîfât, Beyrut 1996, s. 147

23 Hasan Çelebi b. Muhammed Şah el-Fenânî, Haşiyetï Şerhi'l-Mevâkıf (Şerhu'l-Mevâkıfla birlikte), VIII, 172. 
5-el-îcî, et-Taftazânî ve el-Cürcânînnin tanımlarında dikkat çeken bir husus da rızkun Allah'a nispet edilmesidir. Taftazânî, diğer tariflerin Allah'a nispet edilmekten yoksun olduğunu belirterek rızkın Allah'a izâfe edilmesini tanımın önemli bì unsuru saymıştır. ${ }^{24} \mathrm{Bu}$ da yegâne rızıklandırıcının (Rezzak) Allah olmasindan ve Kur'an'in rızık kelimesini daima Allah'a nispet etmesinden kaynaklanmaktadır.

Rızkın sadece gıdalanılacak şeyler olarak tanımlanması, bazı kelâmcılar tarafından dar kapsamlı bulunmuştur. Bu yüzden tanıma, gıdalanma/yemeiçme kelimelerinin yerine daha genel bir anlamı ifade eden faydalanma kelimesini koyarak tanımlamanın daha uygun olacağı kanaatine varmışlardır. İşte bunlardan birisi olấn Kâdî Abdülcebbâr, nzkın yenilen-içilen şeyler olarak tarif edilmesini tenkit ederek; evlatların ve malların da Allah tarafından verilmiş rızıklar olduğúnu, ancak onların yenilip içilmediğini söylemiştir. ${ }^{25}$ Kâdî Abdülcebbâr'ın bu eleştiriden amacı, rızkın tanımının bu kadar dar tutulmaması gerektiğini vurgulamaktır.

Bu bağlamda Kâdî |Abdülcebbâr rızkı, mutlak ve muayyen olmak üzere ikiye ayırmış, bir şeyin rızık olabilmesi için ondan faydalanmak gerektiğini söylemiştir.

1-Mutlak rızık: Su, ot, av ve denizden yakalanan mübah gıda maddeleri olup, bunlardan yararlanabilmek için her hangi bir engel yoktur. Kimse onlara sahiplenemez, , kim önce davranırsa o istifade eder ve onun rızkı olur. Bunlar hayvanlar için de rızıktır. Faydalanma uygunsa ve faydalanmaya engel bir şey de yoksa, o şeyin insanlar veya diğer varlıklar için rızık olmasi arasında herhángi bir fark yoktur.

2-Muayyen rızlk: Șahip olduğumuz şeylerdir. Ancak onlar sırf elde bulundurmak ve sahip olmakla değil, bizzat, tasarruf ve istifade etmekle rızık niteliğine kavuşurlar. ${ }^{\frac{1}{2}}$ i

Kâdî Abdülcebbâr'ın rızık tanımında rızkın lügat manasını, yani onun faydalanılan şey anla!nını temel unsur olarak kabul ettiği anlaşılmaktadır. Böyle bir yaklaşımla o, rızka geniş bir çerçeve çizerek; herhangi bir engel bulunmaksızın yeme, içme, giyme vs. gibi her türlü yararlanma şeklini rizıklanma olarak değérlendirmiştir. Ayrıca, haram rızık değildir demekle r1zık olgusuna ahlâki açııdan yaklaşmıştır.

İmamü'l-Harameyn el-Cüveynî, Ehl-i sünnet bilginlerinin tanımlarının sınırını genişletmek ámacıyla rızkı, sözlük anlamından hareketle faydalanı-

* Taftazânî, Şerhu'l- Akâid, s. 127.

s Kâdî Abdulcebbar, Serhú usuli'l-hamse, thk. Abdülkerim Osman, Kahire 1988, s. 787.

đo Kâdî Abdülcebbàr, el-Mưğnî, Kahire 1965, XI, 27. 
lan şeyler olarak tarif etmiştir. ${ }^{27}$ Buna göre faydalanılan şeyler rızkın kapsamına girer, ama kişinin sahip olup da faydalanmadığı şeyler rızık sayılmazlar.

Taftazânî Şerhu'l-Makâsıd adlı eserinde ise yukarıda ondan naklettiğimiz tanımdan farklı olarak yeme tabiri yerine faydalanma ifadesini kullanmış ve rızkı "Allah Teâlâ'nın, faydalanması için canliya verdiği şeydir"28 diye tanımlamıştır. Bu ifadeyle tanımın kapsamını genişletmiş ve böylece yenilen şeylerin dışında faydalandığımız diğer şeyleri de tarifin içine sokmuştur.

İbn Haldun da aynı fikre katılarak kişinin sahip olup faydalanamadığı şeyleri rızık değil, kesb (kazanç) olarak isimlendirmektedir. Bunu, "Ölen kimsenin miras olarak buraktı̆̆ şeyler, kendisi faydalanamadı̆̆ için, kesbîdir. Varisleri faydalandıkları zaman, onlar için rızık olur" cümlesiyle açıllar. ${ }^{20}$

Kemaleddin el-Beyâzî rızkı, "Gıdalanması, ya da başka bir yolla faydalanması için Allah'tn canlıya verdiği şey" olarak tarif etmiş̧tir. ${ }^{30}$ Bu tanım yemeiçme ile beraber giyme, kullanma gibi başka türlü faydalanma biçimlerini de içine alır. Ayrıca Taftazânînnin hassasiyet gösterdiği rızkın Allah’a izafe edilmesini de içerir.

İbrahim el-Bâcûrî bu tanımdaki faydalanmayı bilfiil ifadesiyle kayıtlamıştır. ${ }^{31}$ Ona göre her hangi bir kimsenin, sahip olduğu fakat bilfiil faydalanmadığı şey onun rızkı olmaz. O şey, kendisinden faydalanan kimse için rızıktır. Zenginin verdiği bir sadaka, kendi rızkı olmayıp, eğer faydalanırsa fakirin rızık olur.

Elmalılı Hamdi Yazır da Bakara sûresi 3. ayetindeki rızık kelimesinin maddî şeylerle beraber manevî şeyleri de içine aldığını, rızkın tanımındaki yeme ifadesinin faydalanma ile açlklanarak içecek, giyecek, ilim, marifet, kudret, amel, evlat ve zevceye de şamil olduğunu, yani mutlak bir faydalanma ifade ettiğini söylemektedir. Fakat o da bütün bunlar için bilfiil faydalanmayı şart koşar ve bilfiil faydalanılmayan şeylerin rızık olmayacağını ifade eder. ${ }^{32}$

Bazı kelâmcılar ise faydalanma şartı olmaksızın elde bulundurulan maddelerin de rızk kavramının kapsamına girmesi gerektiği düşüncesindedirler. Bu husustaki ilk tanımlama Mu'tezile bilginlerinden Ebu'l-Hüzeyl el

J İmamü'l-Harameyn Abdülmelik Cüveynî, el-İrşâd, Beyrut 1985, s. 307.

* Sadeddin Taftazânî, Serhu'l-Makâsıd, Beyrut 1988, IV, 318.

* İbn Haldun, Mukaddime, çev. Süleyman Uludağ, İstanbul 1983, s.343.

x Beyâzî, a.g.e., s.235.

31 Ibrahim Bâcûrî, Şerhu Cevhereti't-tevhid, Dımaşk 1972, s.441.

Yazır, Hak Dini, I, 192, VII, 5230. 
Allafa nispet edilmekte ve onun rızkı ikiye ayırdı̆̆ı söylenmektedir. Bunlardan birisi, Allah'ın kullara rızık olmak üzere yarattığı faydalanılacak şeyler, diğeri ise kullarına|verdiği bu rızıktan helâl ve haram diye belirledikleridir. Helâl kıldığı onun rızkıdır, haram kıldığı ise rızkı değildir. ${ }^{33}$ Ebu'lHüzeyl'in sözlerinden|anlaşılmaktadır ki o, faydalanma olmasa da elde bulunan şeylere rızık adını vermektedir. Ayrıca rızkı sadece insanla ilişkilendirerek ahlâkî alaná çekmekte ve haram olan bir nesneyi rızık olarak kabul etmemektedir. Bú onun diğer canlıların rızıklanmadığına dair bir görüş taşıdığından değil, yalı̣ızca insan rızkını tartışma konusu yaptığından kaynaklanmaktadır.

Ebu'l-Hasen el-Eş'arî̀nin (ö. 324/936) Makâlat'inda genel bir nispetle Ehl-i Sünnet'in rızkı, Állah'ın insana mülk olarak verdiği şeyler ve haram dahi olsa insana gıda ólarak verdiği şeyler şeklinde ikiye ayırdıklarını söylemektedir. ${ }^{34}$ Bu tanımlama Ebu'l-Hüzeyl'in tanımıyla kalıp olarak benzerlik arzetmekte ancak, haramın rizık sayılıp sayılmaması noktasında ondan ayrılmaktadır.

Ebu'l-Hüzeyl'in veya Eş’arînin kendilerine görüs nispet ettiği Ehl-i sünnetin, faydalanma olmasa da elde bulunan şeyleri neden tanımın kapsamına aldıklarına dair her hángi bir açıklama yapılmamakla birlikte bu şekildeki anlamlandırma, daha sonra temas edeceğimiz üzere muhtemelen rızık kelimesinin Kur'anda geniş kapsamlı olarak kullanılmasından kaynaklanmaktadir.

Ebu'l-Muin en-Nesefí de rızık kelimesinin bazen gıdalandığımız şeyler için, bazen de sahip olduğumuz şeyler için kullanıldığını söylemektedir. ${ }^{35}$ Bu tarif, Eş'arînin Ehl li sünnete atfettiği tanımlamaya uymaktadır.

Rızık kavramının daha geniş bir anlam alanına sahip olması gerektiğini düşünen Gazâlî de rızkı dört gruba ayırarak tanımlamaya çalışmıştır.

1-Mazmun (garantí altına alınan) rızık: Diğer sebepler olmaksızın bünyenin hayatiyetini sağlayan gıda gibi şeylerdir. Cenab-1 Hak bu nevi rızkı garanti etmiştir.

2-Maksum (taksim edilmiş) rızık: Yiyecek, içecek ve giyeceklerden Allah'ın insanlara taksim edip Levh-i Mahfuz'da yazdığı şeylerdir. Bunların her biri yazıldığı şekilde, muayyen zamanlarda ve belirlenmiş miktarlarda verilir, artmaz, eksilmez, erken gelmez ve gecikmez.

i3 Ebul-Feth Muhammed eș-Şehristânî, el- Milel ven-nihal, thk. Muhammed Seyyid el-Kilânî, Beyrut 1986, II, 53.

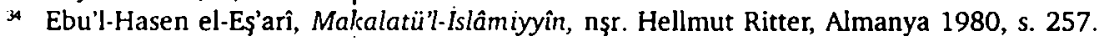

Ebu'l-Muin en-Nesefi, Tabstratül-edille, thk. Hüseyin Atay, S. Ali Düzgün, Ankara 2003, II, 279. 
3-Memluk (sahip olduğumuz) rızık: Dünya mallarından Allah'ın takdir ederek insanların mülkiyetine verdiği şeylerdir. Zira Allah'ın; "Sizi rızıklandırdığımız şeylerden infak edin" 36 emri, malik olduklarınızdan infak edin demektir.

4-Mev'ud (va'd edilen) rızık: Allah'ın müttakî kullarına takva şartıyla, helâl yoldan ve meşakkatsiz olarak vermeyi vad ettiği rızıklardır. Nitekim; "Kim Allah'tan sakınırsa Allah ona bir kurtuluş yolu hazırlar ve ummadı̆̆ yerden rızıklandırır" 37 ayetinde bahsedilen rızık bu tür içerisinde değerlendirilir. ${ }^{38}$

Görüldüŭü gibi İmam Gazâlî, bedende kullanılarak veya depo edilerek vücudun kıvamını sağlayan şeyleri, sahip olduğumuz malları, yediğimiz, içtiğimiz ve giydiğimiz şeyleri ve bize va'd olunanları rızkın kapsamı içine dâhil etmiştir. Bu verdiğimiz bilgilerden anlaşllıyor ki tanımda taksimi tercih eden kelâmcılar, sahip olduğumuz fakat istifade etmediğimiz, başkalarını da istifade ettirmediğimiz şeyleri de göz önünde bulundurarak bu tarifin kapsamını biraz daha geniş tutmak amacıyla bunu yapmıslardır.

Ruzkın sadece yenilen-içilen/faydalanılan şeyler olarak tanımlanmasına karşı çıkan kelâmcılardan biri de Fahreddin er-Râzî'dir. Râzî, Allah'ın "Sizi rızıklandırdığımız şeylerden infak edin" ${ }^{39}$ ayetiyle, rızıklandırdığı şeylerden infak etmemizi emrettiğini, rızık yenilen şeyler olarak tarif edildiği takdirde yediğimiz şeylerin infakının bizden istenmiş olacağını, böyle bir infakın ise mümkün olmadığını ileri sürerek bu tanımın yanlış olduğunu söyler. ${ }^{40}$ Ona göre elde bulundurulan şeyler de rızık kapsamına alınmalıdır.

Ibn Teymiye de rızkı, sahip olduğumuz şeyler ve faydalandığımı şeyler olarak ikiye ayııı, ancak o, faydalanmayı yiyerek faydalanma şeklinde açıklığa kavuşturur. ${ }^{4 l}$

Bu tanımlama biçimi Şiî müfessirlerden Tabatabâî tarafindan da kabul görmüştür. Tabatabâî rızkn, gıdalanılan şeyler veya insana verilen maddîmanevî şeyler ya da faydalanılan şeyler gibi muhtelif kapsamlı olarak kullanıldı̆̆ı ve bu kullanımların hepsinin de doğru olduğu kanaatini taşımaktadir. ${ }^{42}$

\footnotetext{
el-Münafikûn $63 / 7$.

et-Talâk $65 / 7$.

* Muhammed b. Mahmud el-Gazâlî, Minhâcü"l-âbidin ( Sirâcu't-talibin ile birlikte), Kahire 1953, s. 88-97.

el-Münafikûn $63 / 10$.

- Râzi, Tefsir, 2/30.

4l Takiyüddin b. Ahmed İbn Teymiye, Mecmuu'l-fetava, Beyrut h.1398, VII, 581.

- Muhanmed Hüseyin et-Tabatabâî, el-Mizan fi tefsiri'l-Kur'an, Beyrut 1972, III, 137.
} 
Demek ki rızkın faydalanılan şeyler olarak tanımı esas alınabilir ve yeme-içme daha genel bir ifade olan faydalanma kelimesiyle açıklanabilir. Faydalanılmasa bile faydalanmak üzere elde bulundurulan şeyler de rızık kapsamına sokulabilir. Daha sonra bahsedeceğimiz üzere bu tür bir yaklaşım, rızkın hem dildeki yaygın kullanılışına, hem de dinî metinlerde kullanılışına uygun dî́şmektedir.

\section{b) Meşruiyet Sorunu}

Rızkın yukarıda zikredilen tanımlarında dikkatimizi çeken diğer bir problem de haram bir şeyín rızık olup olmayacağı tartışmasıdır. Bizzat haram olan (haram li'aynihi), yani Şari' tarafından haram olduğu bildirilen veya bizzat helâl olduğu hálde haram bir yolla elde edilmiş olan (haram li gayrihi) bir şeyin insana rrızık olup olmayacağı konusu da kelâmcılar tarafindan geniş bir şekilde tartışılmıştır.

Ehl-i Sünnet bilginleri helâl olan bir şeyi rnzık olarak kabul ettikleri gibi, haram olan bir şeyi dé rızık olarak kabul ederler. Çünkü insan/canlılar, helâl olan bir şeyle beslendiği gibi, haram olan bir şeyle de beslenebilir. Rızkın helâl (meşrû) veya haram (gayr-1 meşrû) olması ahlâkî-hukukî bir sorundur. Halbuki bir şeyin rızık olup olmaması, canlının ondan yararlanması ya da dar anlamda onunla beslenmesiyle ilgilidir. İlk dönemlerden itibaren yapılan bu tanımlamá daha sonraki Ehl-i sünnet kelâmcıları tarafindan da benimsenmiştir. ${ }^{43}$

Ehl-i Sünnet kelâmciları Mu'tezile bilginlerinin, rızk malikin mülkünden faydalandı̆̆ ya da kendisinden faydalanmaya herhangi bir mani bulunmayan şey olarak tarif ettiklerini söylemektedir. ${ }^{44} \mathrm{Bu}$ tanımlardan birincisinde mülkiyet şartı 'konulması haram ligayrihiyi rızkın kapsamı dışında tutmak içindir. İkincisi ise daha geniş kapsamh olup haram li'aynihiyi de tanımın içine almaktadır.

Mu'tezile haramı kötü saydığı için, "Allah haramla kullarını rızıklandırdi" demeyi uygun görmemektedir, ancak bu durumda haram bir şeyle rızıklananların rızkı kimé nispet edilecektir? İşte Ehl-i Sünnet bu konuda Mu'tezile'yi tenkit ederek; "Eğer haram rızık değilse, haram yiyenler rızıklanmıyor mu? Şayet rızıklanıyorsa onlan Allah'tan başka biri mi rızıklandırıyor?" gibi sorular yöneltmişlerdir. ${ }^{45}$ Ayrıca Ehl-i sünnet kaynaklannda Mu'te-

43 Ebul-Feth Muhammed eş-Şehristânî, Nihâyetü'l-ikdâm fí ilmi'l-kelâm, nşr. Alfred Guillaum, Kahire ty., s. 415.

- Taftazânî, Şerhu'l-akâid, s.128; a.mlf., Ta'rîfât, s. 147; Aliyyü'l-Kânî, Şerhu Fikhil-ekber, Beyrut 1987, s.191.

- Eşarî, Makâlât, s. 247; Ebu Bekir el-Bâkullâni, Temhidü'l-evâil ve Telhisü'd-delâil, Beyrut 1987. s. 328-329; Sâbûnî, a.g.e., s. 75; er-Râzî, a.g.e., Il, 30-31; Bâcûrî, a.g.e., s. $442-443$. 
zilîlerin, "Kul fillini kendi yapar" yaklaşımlarından hareketle haram yiyenin de kendi kendini rızıklandıracağı görüşünde oldukları ileri sürülür. ${ }^{46}$

Ehl-i Sünnet kelâmcıları, bir şeyin canlıya rızık olabilmesi için onun, kişinin mülkü olması gerekmediği görüşünü savunmuş ve Mu'tezile’nin, rızkı mülk olarak tarif etmelerini tenkit etmişlerdir. Mu'tezilenin bu görüşünün yanlışlığını ispat etmek için, "Şayet rızıkda mülkiyet şart ise, her şey Allah'ın mülküdür; o halde her şey Allah'ın rızkıdır" demek mümkün müdür? Yine, çocukların emdiği sütlerle, hayvanların yediği otlar mülkleri olmadığına göre onların rızıkları değil midir?" gibi sorular yöneltmişlerdir. ${ }^{47}$

Ancak Mu'tezileye nispet edilen bu rızık tanımlaması bütün Mu'tezililerin ortak görüşünü yansıtmamaktadır. Çünkü Mu'tezilîler bu konuda ittifak içerisinde değildirler. Meselâ Ebu Hâşim el-Cûbbâî̀nin (ö.321/933) görüşlerini tercih ederek izahlarını o doğrultuda yapan Kâdî Abdülcebbâr ve bağhı bulunduğu ekol, Mu'tezileye nispet edilen bu rızık anlayışına muhalefet ederek rızka mülkiyet şartını koymamıştır. Kâdî Abdülcebbâr rızkı, faydalanılan şeyler olarak tarif etmiş ve rızkın gerçekleşebilmesi için faydalanmayı engelleyecek bir şeyin olmamasını şart koşmuştur. $O$, faydalanma olmadığı takdirde bir şeyin insanın mülkü olsa da rızkı olmayacă̆ını ileri sürmüştür. ${ }^{48}$ Aynı zamanda o, üstadı Ebû Ali el-Hallad'ın elUsûl isimli kitabında rızkı böyle tarif ettiğini ve ekolün üstadlarından Ebu Haşim el-Cübbâî'nin (ö. 321/933) de aynı görüşte olduğunu söyler. ${ }^{49}$

Rızkın mülk olarak tanımlanmasını kabul etmeyen ve hatta böyle bir tarifin olur yönü bulunmadığını söyleyen ${ }^{\text {so }}$ Kâdî, bu hususu şöyle izah etmektedir:

"Mülkiyet rızık olmayı gerektirmez. Bir şeyin birisine rızı olmast için onun sahibi olması ve malikin mülkünü kendine tahsis ettiği gibi tahsis etmesi şart değildir. Çünkü rızlk olarak tahsis etmek, tasarruf etme veya tasarrufun faydasinı elde etmek üzere sahip olmayı gerektirir. Bu sebeple insanın sahip olmadı̆̆ı, meselâ başkasının verdiği yiyecek gibi bir şey de olsa, kullanması ve faydalanması mubah olduğunda onun için rızık olur. Yine hayvanların istifade ettiği şeyler onların rızkı olsa bile mülkü değildir. Çocuklar ise her ne kadar mükellefiyeti gerektirecek seviyede akıllı olmasalar da durumlar hayvanlardan farklıdır. Çünkü çocuklar mülklerinin sahipleridir ve tasarrufları-

\footnotetext{
* Nâsınıddin el-ískenderî, el-Insaf (Zemalışeri'nin Keşafıyla birlikte), Beyrut ty., I, 32.

7 Ebu'l Hasen el-Eşañ, el-ibâne an usûli'd-diyane, Beyrut 1993, s. 59-60; a. mlf., Makâlât, s.247; Bâkıllânî, Temhid, s. 328-329; es-Sâbûnî, a.g.e., s. 75; Bâcûrî, a.g.e., s.442-443.

- Kâdî, a.g.e., XI, 30 .

4) Kâdî, a.g.e., XI, 29-30.

so Kâdî, a.g.e., XI/30.
} 
nın faydası mümkündür. Dolayısıyla sahip oldukları şeylerde akıllı/mükellef konumundadirlar." 5.

Kâdî Abdülcebbâr meseleyi sadece mülkiyet açısından düşünüyor, oysa diğer Mu'tezililer hırssılzlı, gasp gibi haksız yollarla elde edilmiş haram li gayrihi olan şeyleri tánımın dışında tutmak için mülkiyet şartını koymuşlardır. Mezhebin sistématiği açısından diğerlerinin yaklaşımı daha tutarlı gözükmektedir.

Şî̂ müfessir Tabersî, itikadi konularda genellikle Mu'tezile ile aynı düşündüğünden rızkı, Kíâdî Abdülcebbâr gibi tanımlamıştır. Ona göre de rı$\mathrm{zlk}$, "Kendisinden faydalanılmast uygun olan ve istifadeye bir engel bulunmayan şeydir." 52

Daha önce belirtildiği gibi Mu'tezilîler rızkın tarifine yararlanmaya bir engel bulunmaması şártını koymuşlardır. ${ }^{53}$ Onların bu şartı, ister liaynihi olsun isterse ligayrihi olsun, haramı rızkın kapsamı dışında tutmak için ileri sürdükleri görülmektedir. Bunu ise üç temel esasa dayandırırlar: 1Haramla rızıklandırmáa onların salâh-aslâh anlayışlarına ters düşmektedir. Çünkü onlar, Allah'ın' kullanı için aslâh/en iyi olanı yapmasının vacip olduğu inancını taşırlar. Buna göre Allah kullarını helâl olan şeylerle rızıklandırmalıdır. ${ }^{54}$ 2-Onlar Allah'ı tenzih maksadiyla kabih (kötü) olanı Allah'a isnat etmeyi uygun görmezler. Haram da kabih olduğundan onu Allah'a nispet ederek kullarını haramla rızlklandırdı demeyi inanç bakımından doğru bulmazlar. ${ }^{55}$ 3-Mu'tezile'ye göre, hüsün ve kubuh aklî olup, teklif de aklî olan hüsün ve kubhấ göre yapıldığından onlar haramı rızık saymamaktadırlar. Çünkü onlara göre haram olan şey bizzat kötüdür. Allah da o sebeple onu yasaklamıştır.|O, yasakladığı bir şeyi kullarına rızık yapmaz. ${ }^{56}$

Ne var ki Mu'tezilenin bu üç temel anlayışı da Ehl-i sünnet tarafından tenkit edilmiştir. Buña göre Mu'tezile Allah'ı herhangi bir fiille zorunlu tutmuş olmaktadır ki, Éhl-i sünnet kelâmcıları Allah'n mutlak iradesine zorunluluk nispet edilemeyeceğini savunurlar. Ayrıca kabihliğin, rızkın yaratılıp kullara ulaştırılmasında mı yoksa insan iradesinin kötüye kullanılmasında mı olduğunun áyırt edilememesini de bir başka eksiklik olarak görürler. Allah'ın rızkı yaratması ve kullarına ulaştırmasında kabihlik yoktur. Allah, haramı rızı olarak tercih etmeleri konusunda kullarını zorlamaz. Hat-

Sı Kâdî, a.g.e., XI, 27-28.

5. Ebu Ali el-Fazl b. El-Hasen et-Tabersî, Mecmau'l-beyan, Beyrut ty., I, 83.

s: Kâdî. a.g.e., XI, 30.

4 Kâdî, a.g.e., XI, 47.

ss Kâdî, a.g.e., XI, 40.

ç Kâdî, a.g.e., XI, 40. 
ta onların rızıklarını helâl olan şeyden ve helâl yoldan talep etmelerini ister. Fakat kul haramı tercih ediyorsa Allah da ona istediğini verir. Eğer kulun istediğini Allah vermezse o zaman insanın dünyada imtihan için bulunmasının manası kalmaz. Çünkü bu durumda, kul için zorunluluk söz konusu olur ve dolayısıyla onun sorumluluğu üzerinden kalkmıs olur. Halbuki Allah insanı, yarattı̆̆ı şeylerle değil, teklifleriyle, yani emir ve yasaklaryyla imtihan etmektedir. Meselâ, Allah sarhoşluk veren bir içeceği yaratmakla değil, onu içmeyi yasaklamakla insanı imtihan eder. Tercih eden insan olduğu için hüsün ve kubuhla, yani iyilik ve kötülükle onun fiilleri sıfatlanır. Insanın itab ve ceza görmesi de fiilinin kabih olmasındandır. Yoksa Allah'ın yaratması daima iyidir. Bazı şeylerde zararın ve dolayısıyla kötülügün olması da bazı hikmetlere binaendir.

Ehl-i sünnetin bu eleştirilerini Kâdî Abdülcebbâr'ın göz ardı ettiği görülmektedir. Hatta o, konuyu takdir noktasindan ele almakta ve rızkn takdir edilmesiyle haramın rızık olmasını birbiriyle bağdaştıramamaktadır. Bunun için Kâdî Abdülcebbâr, hırsızın çaldığı şeyi Allah'ın hırsıza rızık yapmasının, sonra da eşyası çalınan kimseye eşyasını geri almasını, idarecilere hırsızı cezalandırmalarını ve diğer insanlara da hırsızı kötülemelerini, ondan uzak durmalarını emretmesinin nasıl mümkün olduğunu sorar. Ona göre bu mümkün değildir. ${ }^{57}$ Hatta bunun da ötesinde o, "Allah birini haramla rızıklandırıyorsa bu, onu Allah'ın ezelde takdir ve taksim ettiği ve dolayısıla kulun da bu takdire rıza göstererek yemesi gerektiği neticesine götürür ki böyle bir neticeye varmak insanı dinden çıkarır"s8 diyerek kendisini haklı çıkarmaya çalışmaktadır. Bu sözlerden anlaşılmaktadır ki, kader veya takdir denilince Mu'tezile'nin aklına cebir anlayısı gelmektedir. Bu yüzden de onlar, kulların iradî fiillerinin Allah tarafından takdir edilmediği inancını taşımaktadırlar. Allah'ın takdirini bu şekilde anlamaları onları isabetli olmayan bir sonuca götürmektedir.

Kâdî Abdülcebbâr, haramın rızık olmadığına dair görüşlerini desteklemek için bir takım naklî deliler de ileri sürmektedir. Bu delillerden birincisi, "Kendilerini rızıklandırdığımız şeylerden infak ederler"s9, ikincisi ise; "Sizi rızıklandırdı̆̆ımı şeylerden infak edin" ${ }^{\prime \prime 0}$ ayetleridir. Bu ayetlerin birincisinde Allah, infak edenleri övmekte, ikincisinde ise infakı emretmektedir. Kâdî Abdülcebbâr, "Eğer haram rızık olsaydı onu infak eden de övgüye hak kaza- 
nırdı ve Allah onun infakını da emretmiş olurdu ki bunlar mümkün değildir. Meselâ, gasbedilmiş bir şeyin infakı caiz değil, bilakis onu sahibine geri vermek vaciptir"!der. ${ }^{61}$

Bize göre bu iki ayetteki rızıkdan, rızık olmak üzere verilen şeyler kastedilmektedir. Yani henüz faydalanılmamış, ama insanın elinde bulunan şeydir. İnfak bu mülkten istenmekte ve övülmektedir. Yoksa insanın yiyip tükettiği şeyi infak etmési zaten mümkün değildir. Diğer yandan Kâdî Abdülcebbâr'ın dediğine göre elde bulunan bir şey henüz kullanılmamışsa o, rızık değildir. Dolayisıyla bu iki ayetin Mu'tezilenin iddiaları için tutarlı birer delil olmadıklaț söylenebilir.

Mu'tezile'nin nakli delillerinin üçüncüsü, "Allah'ın lütfundan rzzık ararlar"62 ; dördüncüsü ise, "Diğerleri de yeryüzünde gezer ve Allah'ın lütfundan rızlk ararlar"63 ayetleridir. Mu'tezileye göre bu iki ayette Allah, lütfunun kullar tarafından talép edilmesini istemektedir. Şâyet haram rızık olsaydi, Allah onun da talebini istemiş olurdu. Böyle bir şey ise mümkün değildir. ${ }^{64}$

Halbuki Allah bu, ayetlerde helâlin talebini istemektedir. Zaten helâli fazl (lütuf) olarak nitelendirmiştir. Ama kullar Allah'ın bu isteğinin dışına çıkıp rızkı haram yolddan taleb ediyorlarsa bunun sorumluluğu kula aittir. Çünkü rızku haram ollarak taleb eden insandır. Netice olarak bu iki ayetin de onlara delil olmaktan uzak olduklarını söyleyebiliriz.

Öte yandan Mu'tézile'nin kendilerine delil olarak kullandıkları Safvan b. Ümeyye hadisi de bilakis onların aleyhine delildir. Bu hadiste anlatıldığına göre Amr b. Kurre Hz. Peygamber'in yanına gelerek "Ey Allah'ın Resûlü! Allah bana şekaveti takdir etti. Bu sebeple rızkımı elimle f̧aldığım defimde görüyorum. Ahlâksızllk telkin etmediği sürece şarkı söylemem için bana izin ver" demiş, Hz. Peygamber de ona cevaben, "Sana ne izin, ne ikram, ne de nimet vardır. Ey Allah'in düşmant! Yalan söyledin. Allah seni güzel rızıklarla rızıklandırdı ama sen, Allah' in sana helâl olarak verdiği rıkkın yerine haram kıldığı rızkını tercih 'ettin" buyurmuştur. ${ }^{65}$ Bu hadisteki "Sen Allah'ın sana haram kıldığı rızkını' tercih ettin" sözü haramın rızık olduğunu açıkca ifade etmektedir ki, böyle bir delil onların lehine olarak algılanamaz.

Mu'tezilenin delililerinin beşincisi, "Yetimlerin mallarını haksı yere yiyenler karınlarına ateş doldurmuş olurlar" ${ }^{\prime \prime 6}$ ayetidir. Bu ayette haksız yere

a) Kâdî, a.g.e., XI, 35.

Q el-Cuma $62 / 10$.

is el-Müzemmil 74/20.

* Kâdî, a.g.e., XI, 36.

* Ibn Mace, Hudud, 38.

(i) en-Nisa 4/10. 
yetim malı yemenin karna ateş doldurmak olduğu bildirilmektedir. Mu'tezilîler, haram rızık olsaydı Allah onu, karna ateş doldurmak olarak nitelemezdi demektedirler. ${ }^{67}$ Halbuki ayetin onlara delil olamayacağ 1 hususu çok açıktır. Çünkü ayet haksız yere yetim malı yemenin kötülügünü anlatmaktadır.

Onların delillerinden altıncısı, "De ki: Allah'in size verdiği rzzkın bir kısmını haram, bir kısmını helâl kıldığnızı görmüyor musunuz? De ki: size Allah mi izin verdi yoksa Allah'a karşı yalan mı uyduruyorsunuz?"68 ; yedincisi ise; "Beyinsizlikleri yüzünden körü körüne çocuklarını öldürenler ve Allah'ın kendilerine verdiği nimetleri Allah'a iftira ederek haram sayanlar mahvolmuşlardir"69 ayetleridir. Mu'tezilîler bu iki ayetin de kendileri için delil olduğunu iddia ederek, haram rızık olsaydı insanların bazı şeyleri helâl, bazı şeyleri de haram saymalarını Allah zemmetmezdi demektedirler. ${ }^{70}$

Ancak bu iki ayetin de konuyla ilgisi bulunmamaktadır. Bu ayetler hükmün Allah'a ait olduğunu, insanın kendi kafasından hükümler koymasının, haddi aşmak olduğunu ifade etmektedir.

Bütün bu delillerin incelenmesinden Mu'tezile'nin kendi iddialarını desteklemek için ileri sürdükleri delillerin hiç birisinin onlar için geçerli birer delil olmadığı anlaşılmaktadır. Bu durumda onların haramı rızık saymama yaklaşımları, hem Kur'an'a, hem hadise hem de kendi temel kurallarına aykırı gözükmektedir.

Şî̉ler de Mu'tezile gibi haramı rızık olarak kabul etmemişlerdir. Onlar da bu konuda Bakara sûresinin 3. ayetini delil gösterirler. Ancak Şiî bilginlerden Tabatabâî Ehl-i Sünnet ile Mu'tezile arasında orta bir yol ile problemi halletmeye çalışmaktadır. O, yaratma cihetiyle haramı rızık saymakta ise de teşri cihetiyle rızık saymamakta, dahası bu ikisi arasında her hangi bir zıtlık da görmemektedir. ${ }^{71}$ Muhammed Bâkır el-Mecâlisî de konuyu aynı şekilde izah eder:

"Hayatın devamı rızka bağlıdır. Allah rızkı bu sebeple yaratmışr. Bu yönüyle rizık tekvînî bir emirdir. Yaratma cihetiyle rizik zorunludur ve bu cihetten ona haramlik taalluk etmez. Ama insanin filli olarak onu elde etmesine teklif taalluk eder. Bunda da haramlik helâllik söz konusudur. Teşrî̀ rızık, insanın hayatında kullandığ, haram olan değil, helâl olandır. Çünkü haram, Allah'in meşrû kıldığı rızık değildir."72

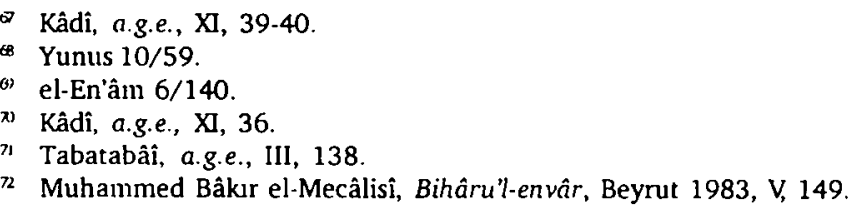


Şîa bilginlerinin bu izah tarzı da anlaşılır gibi değildir. Çünkü, tekvînî cihetten rızık olan bir şey, sonra kulun tercihinin kötü olması sebebiyle, rızık ismini nasıl ve|neden yitirmektedir? Kaldı ki, el-Mecâlisî, yukarıda zikrettiğimiz; Haram Allah'in meşrû kıldığı rızık değildir sözüyle haramı rızık olarak kabul ettiğini ortaya koymaktadır. Öte yandan Şia'nın bu izah tarzının, Mu'tezile'nin anlayışıyla paralellik arzettiği görülmektedir. Çünkü Mu'tezile de hara'mı Allah'dan başkası yarattı iddiasında değildir. Onlar da konunun teşrîi yönünü problem olarak algılamaktadırlar. Şî'nın Mu'tezile'ye paralel bir izáh tarzı ile bu konuya yaklaşması, onlanın salâh-aslâh, hüsün-kubuh ve kader meselelerinde Mu'tezile ile aynı anlayışta olmalarından kaynaklanmaktır. ${ }^{73}$

Tabatabâî, Kâdî Ábülcebbâr ile aynı görüşü paylaşarak, "Allah insanın rızkını vermeyi üzerine almıstır. Buna göre Allah, insanı hem haramla rızlklandırıp hem de nehy'ederek cezaya çarptırmaktan münezzehtir"74 demektedir. Allah'ın takdir êtmesi olgusuna yaklaşımının farklı oluşu sebebiyle o, problemi karmaşık bir hale sokmuştur. Şîa'nın cebrî bir anlayış içerisine düşmemek için böyle bir yaklaşımda bulunduğu söylenebilir. Halbuki insanın iradî fiillerinde Állah'ın takdirinin kulun iradesi ile beraber olduğu fikrinden çıkış yapılsa iddi cebrî bir anlayış içerisine düşülmemiş olurdu.

Eğer Şia'nın "Teş̧î́ cihetiyle haram olan, Allah tarafindan rızık değildir" sözlerinden maksatları "Haram, yenmesine Allah'ın rzzası olan rızık değildir" demek ise, bu 'kabul edilebilir bir sözdür. Fakat Şî'nın söz konusu ifadeyle bu manayı krasdetmedikleri açıktır. Çünkü Şîa daha önce de belirttiğimiz gibi hüsün-kubuh, salâh-aslâh ve kader konusunda Mu'tezile ile ortak bir anlayışı paylaşmaktadır. Bu yüzden de fikirleri paralellik arzetmektedir.

Anlaşılan o ki rızık tanımlanırken haram veya helâl kaydının konulması pek isabetli değildir. Mu'tezile bu kaydı koyarken rızkı sadece insan için ve hukukî-ahlâkî alanın bir problemi olarak düşündüğü görüntüsü veriyor. Halbuki diğer canlıları da rızıklandırma kapsamı içinde düşünmek gerekir.

Değerlendirme

Buraya kadar verdiğimiz bilgilerden rızı kavramının, hakiki manada yenilerek faydalanılan g̀ıda maddeleri için kullanıldığı anlaşılmaktadır. Rızık tabirinin, yemenin dışında faydalanılan şeyler için kullanılması ise mecazdır. Şehabeddin Máhmud el-Âlûsî (ö. 1872) bunu şöyle ifade etmiştir:

is Abdülaziz Gulam Hakim ed-Dehlevi, Muhtasaru't-Tuhfetü'l-Isnâ Aşeriyye, İstanbul 1979, s. 72 90.

74 Tabatabâî, a.g.e., III, 140 
"Yiyerek istifade ettiğimiz şeylere rızık isminin verilmesi hakikat olup, sahip olduğumuz veya başkalarının istifade etmesi için infak ettiğimiz şeylere rızlk isminin verilmesi ise mecazdır. Çünkü onlar, gerek bize gerekse infak ettiğimiz kimselere rızık olmak üzere verilmiştir.""7s

Hakiki manada rızık, canlının yiyerek gıdalandığı şeylerdir. Nitekim Kur'an'da bu manayı ifade eden ayetler mevcuttur. "Anaların nzkını ve giyeceğini uygun bir şekilde sağlamak çocuk kendisine ait olan babaya aittir"76 ve "Allah'in sizi koruyucusu kılmıs olduğu mallarınızı sefihlere vermeyin. Kendilerini onların gelirleriyle rzzlklandırın ve giydirin"77 ayetlerinde, giyeceğin rızıktan ayn olarak zikredilmesi, bu ikisinin ayrı şeyler olduğunu göstermektedir. Hatta cehennemliklerle cennetlikler arasında geçen bir konuşmayı anlatan A'raf sûresindeki; "Cehennemlikler cennetliklere, bize biraz su veya Allah'in size verdiği rızıktan gönderin"78 ayetinde, suyun rızıktan ayrı olarak zikredilmesi de rızık isminin sadece yenilen şeyler için hakikat olarak kullanıldığını ifade eder. Kâf sûresindeki, "Biz o su ile kullara rızlk olmak üzere bahçeler, biçilecek taneli ekinler, küme küme tomurcukları olan boylu hurma ağaçları yetiştirdik"'9 ayeti de bu fikri desteklemektedir.

Sadece yenilen şeylerin rızka dahil edilmesi ve başka şeylerin tanımın dışında bırakılması, tarifin biraz daraltıldı̆̆ı fikrini vermektedir. Çünkü, rızkın hem lügat anlamı, hem bu konudaki ayet ve hadislerin ifadeleri ve hem de halkın bu kelimeyi mecazi anlamda kullanışı (kullanım örfü) tarifin daha kapsamlı olabileceğini göstermektedir. Rızkın sözlükteki, kendisinden faydalanılan şey, atâ ve pay şeklindeki tarifi esas olarak alınırsa, yenilen içilen şeylerle beraber, kendilerinden diğer yollarla istifade edilen şeylerin de rızkın içine girmesi gerekir. Kur'an'daki, “Kendilerini rızıklandırdığımı şeylerden infak ederler"8" ayeti sahip olduğumuz malların; "Dünya dört kimsenindir. Bunlardan biri de Allah'in kendisini mal ve ilimle rızıklandırdı̆̆ kimsedir"81 hadis-i şerifi ise hem malların hem de ilim gibi manevî şeylerin; "Allahım şeytanı, bizden ve bize rızık olarak vereceğin çocuktan uzaklaştır"82 şeklindeki Hz. Peygamber'in duasının ise çocukların, rızkın kapsamı içine girebileceğini göstermektedir. Hz. Peygamber'in; "İnsan oğlu malım, malım

\footnotetext{
Şehabeddin Mahmud el-Âlûsî, Rûhu'l-maânî, Beyrut ty., 1/117.

el-Bakara $2 / 233$.

en-Nisa 4/5.

el-A'râf $7 / 50$.

Kâf 50/9-11.

el-Bakara $2 / 3$.

Tirmizi, Zühd, 17.

k Tirmizi, Nikâh, 8.
} 
der; senin yiyip tükettiğgin, giyip eskittiğin ve sadaka olarak verip ahiret için ebedileştirdiğinden bașka malın var mıdır?"»3 hadisi de böyle genel bir faydalanmayı anlatmaktádır.

Anlaşılan o ki, yenhilen şeyler dışındaki maddî-manevî faydalandığımız diğer şeyler için rızık teriminin kullanılışı mecazdır. Ruzka sebep olduğu için su, istifade etsek le etmesek de bize rızık olması için verilen mallar ve başkalarına infak ettiklerimiz mecazen rızık olarak adlandırılmıştır.Yiyecek ve gıdalar bedenin rı'ḱkı olduğu gibi; ilim ve marifet aklın; zevce ve evlat da kalbin rızkıdır. İnsanın nasibi olduğu için bu gibi manevî şeylere de mecazen rızık adı verilmistirtir.

Maddî şeylerin dị̧ıında manevî şeylere de rızık adı verilebileceği konusuna Kur'an, Hz. Şuâyb'ın (a.s); "Ey milletim! Rabbimden benim bir belgem olduğu ve bana güzel bir rızık verildiği halde O'na karşı gelebilir miyim?"84 sözünü nakleden ayetiyle işaret etmektedir. Çünkü burada güzel rzzlktan maksat peygamberliktir. ${ }^{85}$ Hatta insanın zevk aldığı, ruhen hoşlandığı ve huzur duyduğu şeyler de rızık konusu içinde değerlendirilebilir. Nitekim bir ayette, "Yeryüzünde rengârenk şeyleri de Allah sizin için yaratmıştır"8o buyurulmaktadır ki, böyle güzel manzaralar psikolojik tatmin vasıtalarıdır ve bunlar da mecazen rızık kapsamında kabul edilmelidir.

Ehl-i Sünnet alimilerinin rızkı farklı şekillerde tanımlamalarının sebebi, onun dildeki kullanı́mıdır. Bazı kelâmcıların, insanın sadece beslendiği gıda maddelerini rızık sáymaları, onun hakiki anlamını esas almalarındandır. Bazı kelâmcıların yẹme-içmenin dışında başka yollarla insanın faydalandığı diğer şeyleri de rízık kapsamı içine sokmaları ise, mecazi anlamını temel almalarından kaynáklanmaktadir. Mu'tezile bilginleri de kendilerine yapılan bazı itirazları dikkate, alarak daha makul bir tanım yapmaya gayret etmişlerdir. Şîa ise genelde Mu'tezile'nin itikad esaslarını benimsediğinden, onların tanımlarına ortak olmuştur. Cüveynî'nin rızkı yararlanılan şeyler olarak tarif etmesi ve Kâdî Abdülcebbâr'ın mülkiyet şartını tariften çıkartmasıyla, ekolle! arası farklılık hemen hemen kapanmış, sadece haramlık problemi bir ihtillaf konusu olarak kalmıştır.

Netice olarak şứnu söyleyebiliriz: Rızık üç kategoride ele alınabilir; 1 Hususi ve dar manasıyla insan bedeninin gücünü ve dolayssıyla hayatın devamını sağlayan 'gıdalardır. Bu bazı kelâmcıların tarifine uymaktadır. 2-

8 Müslim. Rikâk, 29,58.

Hûd 11/88.

*s Ebu'l-Fidâ İsmail İbn Kesir, Tefsiru'l-Kur'ani'l-azim, Beyrut 1969, II, 456.

en-Nahl 16/13. 
Geniş anlamıyla, Allah'ın insana verdiği, yararlansın veya yararlanmasın insanın elinde bulundurduğu mal ve mülktür. Bu da bazı kelâmcıların tarifine ve halkın kullanım örfüne (mecaz) uymaktadır. 3-íktisadi anlamda da insan hayatının devamı için kullanılan, hatta insan elde etsin veya etmesin evrende potansiyel olarak bulunan, insanlığın istifadesine sunulabilecek mal ve kaynakların tamamına rızık adı verilebilir. Bu anlamda rızık iktisadi hayatın objesi olmakta ve iktisat ilmindeki kaynak teriminin ilahi boyutu da içeren bir karşılığı olarak kullanılmıs olmaktadır. Kur'an-ı Kerim'in rızık kelimesini sadece dar anlamda değil, geniş kapsamlı kullanışı konuya ışık tutmaktadir. 